УДК 626/627

\title{
ОХРАНА ОКРУЖАЮЩЕЙ СРЕДЫ ПРИ РАБОТЕ АО «ЗОЛОТОРУДНАЯ КОМПАНИЯ ПАВЛИК»
}

\author{
Ермилова Вероника Андреевна \\ студентка \\ Научный руководитель: Зайцев Антон Иванович \\ старший преподаватель \\ ИМВХС им. А.Н. Костякова \\ ФГБОУ ВО «Российский государственный \\ аграрный университет - \\ МСХА им. К.А. Тимирязева»
}

\begin{abstract}
Аннотация Строительство и эксплуатация предприятий по добыче драгоценных металлов оказывают негативное воздействие практически на все компоненты окружающей природной среды. Золоторудная техногенная система, включающая токсичные отходы переработки золоторудного сырья, складированные в хвостохранилища, нуждается в дальнейшей модернизации и разработке дополнительных природоохранных мероприятий, в частности по охране водного бассейна, атмосферы и рекультивации земель различными методами.
\end{abstract}

Ключевые слова: золоторудная компания, хвостохранилище, складирование хвостов, пыление отвалов, намыв пляжа, рекультивация.

\section{ENVIRONMENTAL PROTECTION DURING OPERATION JSC "PAVLIK GOLD WORKING COMPANY"}

\author{
Ermilova Veronika Andreevna \\ Academic Supervisor: Zaitsev Anton Ivanovich \\ Institute of Melioration, Water Management and Construction \\ Russian State Agrarian University - \\ Moscow Timiryazev Agricultural Academy
}

\footnotetext{
Abstract: The construction and operation of enterprises for the extraction of precious metals have a negative impact on almost all components of the environment.
} 
The gold ore man-made system, including toxic waste from the processing of gold raw materials, stored in tailing dumps, needs further modernization and the development of additional environmental measures, in particular for the protection of the water basin, atmosphere and land reclamation by various methods.

Key words: gold mining company, tailings dump, tailings storage, dusting of dumps, beach reclamation, reclamation.

Объектом исследования в работе является золоторудная техногенная система, включающая токсичные отходы переработки золоторудного сырья, складированные в хвостохранилища, а также угрожающие различным компонентам окружающей среды (ОС).

Цель работы заключается в оценке влияния на экосферу отходов переработки золоторудного сырья предприятия «Павлик», накопленных в результате хозяйственной деятельности.

Для достижения поставленной цели решались следующие задачи: 1. анализ литературных источников по проблеме оценки влияния техногенных систем на экосферу; 2. изучение современного состояние хвостохранилища золоторудного предприятия на источники техногенного загрязнения и оценка его влияние на экосистемы; 3. рассмотрение основных проблем, связанных с воздействием на окружающую среду, возникающих при добыче полезных ископаемых.

Общие сведения: Месторождение «Павлик» находится в Тенькинском районе Магаданской области, в 12 км от крупнейшего в России золоторудного Наталкинского месторождения [1].

Месторождение открыто в 1942 году советским геологом Дмитрием Асеевым и названо в честь его сына. Вообще геолог Дмитрий Асеев работал на Колыме в 1930-1950-е годы, в в 1942 году участвовал в открытии россыпей золота на р. Омчак. Два россыпных месторождения на левых притоках Омчака были названы Асеевым в честь своих детей - Наталка и Павлик. Павлик месторождение штокверкового типа, что обуславливает возможность крупнотоннажной добычи золота открытым способом. Ближайший населенный пункт находится в 20 км. Основным водотоком сооружений хвостового хозяйства является ручей Ванин. Длина ручья 8,7 км (рис. 1 и 2). Участок расположен в зоне вечной мерзлоты. Мощность многолетнемерзлых пород в днище долины реки Омчак составляет 56-120 м, под возвышенностями - 185-317 метров. 


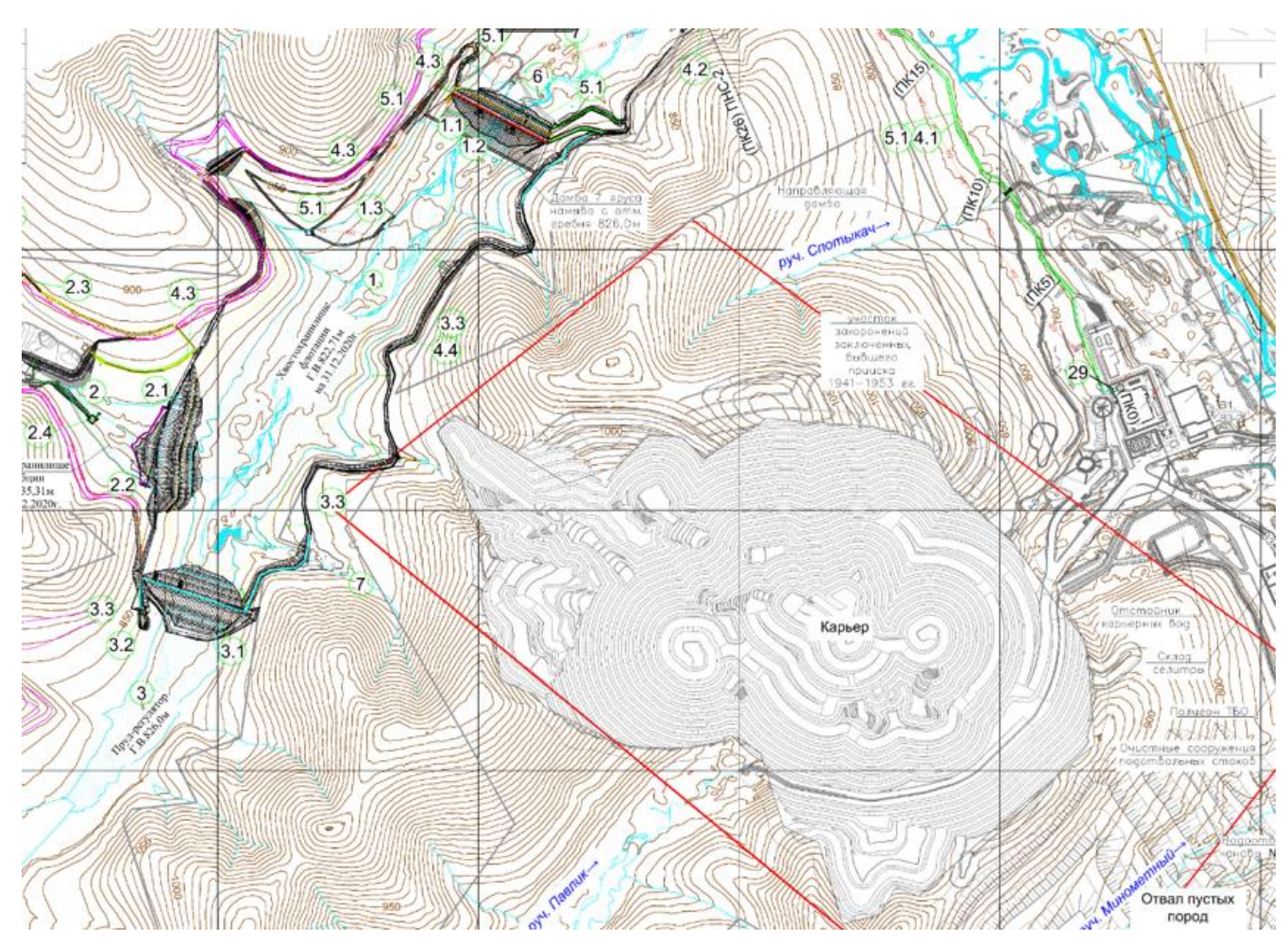

Рис. 1. План сооружений хвостохранилища и карьер.

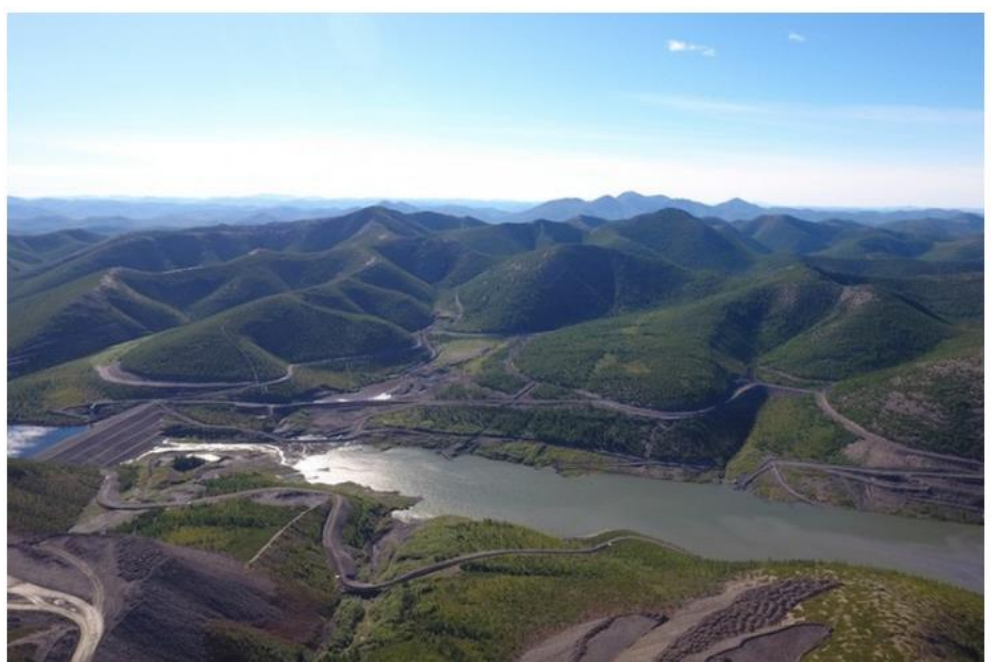

\section{Рис. 2. Вид на сооружения хвостохранилища}

Строительство и эксплуатация предприятий по добыче драгоценных металлов оказывают негативное воздействие практически на все компоненты окружающей природной среды. В процессе извлечения минерального сырья из недр и первичной переработке его на фабриках, при работе машин и механизмов, автотранспорта в атмосферный воздух выделяются загрязняющие вещества. В основном это взвешенные вещества, оксиды азота, серы углерода, а также вещества, используемые в технологии. Отрицательное воздействие на атмосферный воздух может оказывать пыление отвалов при сильных ветрах 


\section{МЕЖДУНАРОДНЫЙ ИССЛЕДОВАТЕЛЬСКИЙ ФОРУМ

Негативное воздействие на атмосферный воздух района сводится к следующему: загрязнение продуктами сгорания топлива двигателей внутреннего сгорания горной и вспомогательной автотранспортной техники; загрязнение пылью при движении автомобилей, бульдозерной и вспомогательной автотранспортной техники; загрязнение пылью при выемке грунта. После завершения строительных работ негативное воздействие на атмосферный воздух может оказывать пыление дамб и чаши хвостохранилища при сильных ветрах в теплый период года.

Основными загрязняющими веществами, содержащимися в сточных водах, являются нефтепродукты и хром (негативно влияют на здоровье человека и экологию в целом). Большое содержание нефтепродуктов в воде приводит к тому, что водоем становится непригодным для использования. Нефтепродукты представлены в основном маслами в виде плёнок [3].

Нарушение земель происходит в ходе ведения выемочных работ техникой в ложе хвостохранилища и размещения породы в тело дамбы. В результате производства строительных работ изменяются характеристики долины. Вместо сглаженного природного рельефа возобладают резкие его формы в виде понижений и возвышений.

Воздействия на растительный и животный мир при реализации проекта можно разделить на прямые и косвенные.1. - прямые связаны с полной трансформацией местообитаний в связи со строительством объекта, 2. - косвенные связаны с воздействием на растительность и животных через выбросы загрязняющих веществ, шум и другие воздействия, сопутствующие эксплуатации хвостохранилища.

В результате работы технологической системы рассматриваемого объекта образуются отходы переработки минерального сырья, складированные в хвостохранилища. Складирование привело к масштабному загрязнению экосферы. Увеличение техногенного влияния на ОС обусловило напряженную экологическую ситуацию в прилегающих территориях горнодобывающих предприятий. Проблема выявления и ликвидации накопленного экологического вреда стоит на повестке дня в РФ (в том числе ДФО) и в мире продолжительное время.

Актуальность изложенного выше вопроса связана с необходимостью: сохранения и восстановления экологически чистой среды обитания, рекультивации поверхности хвостохранилищ, содержащей токсичные отходы, 


\section{МЕЖДУНАРОДНЫЙ ИССЛЕДОВАТЕЛЬСКИЙ ФОРУМ

a также очистки загрязненных площадей в границе влияния отходов переработки минерального сырья горными предприятиями [3].

При устройстве хвостохранилищ загрязнение воздушного бассейна в основном происходит при пылении хвостовых отложений, находящихся в воздушно-сухом состоянии, при высоких скоростях ветра. Следовательно, складирование хвостов необходимо проводить с образованием и постоянным поддержанием надводного пляжа длиной не менее 50 метров, что обеспечит в летний период поддержание хвостовых отложений пляжной зоны в увлажненном состоянии за счет постоянного намыва и капиллярного поднятия воды над кривой депрессии на участках где намыв не производится. При этом проведение намывных работ, которое предусматривает строгую периодичность проходок фронта намыва (т.е. постоянное увлажнение пляжа), исключает возможность пыления складируемых хвостов в намывной период. В климатических условиях месторождения «Павлик» максимальное количество осадков выпадает в июле-октябре, т.е. пляжи хвостохранилища в летний период будут увлажняться и атмосферными осадками.

Для охраны водного бассейна необходимо: устроить дренажные сооружения в нижнем бьефе дамбы, для исключения попадание фильтрующих из хвостохранилища вод в естественные водотоки, подтопления и заболачивания прилегающей территории; предусмотреть аварийную емкость для опорожнения пульповода, для исключение попадания пульпы в нижний бьеф и проводить мониторинг уровня фильтрационного потока и отбор проб воды из нижнего бьефа на химический анализ, на соответствие состава вод ПДК.

Выводы. Данная золоторудная компания активно функционирует, прибыль с каждым годом растет. Несмотря на существующие экологические проблемы, руководство старается минимизировать вред на ОС. Изучив данную компанию можно предложить следующие пути понижение антропогенной нагрузки на окружающую среду: 1 - снижение выбросов в атмосферу загрязняющих веществ, внедрение и применение современных систем очистки промышленных выбросов; 2 - осуществление работ по рекультивации земель, выведенных из производственной деятельности предприятия; 3 - проверка эффективности очистных сооружений и установок; 4 - регулярный мониторинг состояния почвы, воздуха, воды и объектов размещения отходов [4-6]. 


\section{Список литературы}

1. О компании «ПАВЛИК». Открытый доступ: https://www.pavlikgold.ru/about/

2. Зимнюков, В.А., Зборовская, М.И., Абрамова, М.А. Влияние природных факторов на работу шламонакопителя. В сборнике: ДОКЛАДЫ ТСХА. Материалы международной научной конференции. 2018. С. 177-179.

3. Зборовская, М.И., Зимнюков, В.А., Козимиров, Н.Ю. Значение водных объектов в формировании экологического каркаса урбанизированной территории. В сборнике: Экологические и биологические системы. Сер. "Ecological studies, hazards, solutions" Отв. редакторы: С.В. Котелевцев, С.Н. Орлов, О.М. Горшкова, С.А. Остроумов. Москва, 2015. С. 20-23.

4. Зимнюков, В.А., Зборовская. М.И., Белавкин, А.В. Учет экологических факторов при оценке жизненного цикла гидротехнических сооружений. В сборнике: Экологические и биологические системы. Cep. "Ecological studies, hazards, solutions". Отв. редакторы: С.В. Котелевцев, С.Н. Орлов, О.М. Горшкова, С.А. Остроумов. Москва, 2015. С. 23-27.

5. Федеральный закон от 21 июля 1997 года N 117-Ф3 "О безопасности гидротехнических сооружений" (с изменениями на 8 декабря 2020 года).

6. Правила безопасности гидротехнических сооружений накопителей жидких промышленных отходов. ПБ-03-438-02, СПб, ЦОТПБСП, 2002г.

(C) В.А. Ермилова, 2021 